\title{
Population ecology of some medicinal plants of Malam Jabba, Swat, Pakistan
}

\author{
Hassan Sher $^{1 \star}$ and Ali Aldosari ${ }^{2}$ \\ ${ }^{1}$ Centre of Botany and Biodiversity Conservation, University of Swat, Pakistan. \\ ${ }^{2}$ Department of Geography, King Saud University, Kingdom of Saudi Arabia.
}

Accepted 12 June, 2012

\begin{abstract}
A study on the population ecology of three commercially important species namely: Persicaria amplexicaule, Valeriana, jatamansi and Viola serpens was conducted in various ecologically and economically important sites of Malam Jabba, Swat, Pakistan from 2002 to 2004. The altitude of these sites ranged from 1200 to $3200 \mathrm{~m}$. The objectives of the present study were to identify the ecological range, abundance/distribution and phenological stages and population dynamics of each targeted species. Analysis of the population structure (different life stages) of targeted plants species showed that only few individuals of targeted species reached to maturity throughout the investigated area. The results revealed that the density of mature plants reduced 3 to 4 -folds (after collection) than the overall density before collection. But only few plants of the targeted species set their fruits and seeds which were inappropriate for the establishment of their population within the existing vegetational community. The study generally observed that the total biomass in terms of dry weight of each targeted plant was higher at high altitude and most particular in protected sites. All the investigated parameters generally showed an increase of 2 to 4 times in protected sites as compared to the unprotected areas. The study concluded that the conservation of the remaining populations of targeted plants will be best achieved by proper time of sustainable harvesting. It is only possible with the participation of local communities.
\end{abstract}

Key words: Plants population, management practices, local people, collection period.

\section{INTRODUCTION}

Owing to heavy exploitation of the number and population of medicinal plants has become drastically reduced. Traditionally, forests and rangelands are the main sources of medicinal plants in all parts of Swat, which are commonly exploited commercially for decades (Sher et al., 2011). Their cultivation/ex-situ management has been neglected in the past. The evaluation of changes in ecological conditions and their related plant life is often done on the basis of vegetation monitoring. Moreover, shift in densities, frequencies and abundances of targeted plants with a narrow ecological tolerance are frequently used as indicators for assessing change and habitat quality (Sher and Ali, 2012).

*Corresponding author. E-mail: hassan.botany@gmail.com.
A relatively simple approach to describe a species population structures is by determination of the relative densities of the different life stages (Rabotnow, 1985), demographic study of targeted plants (Ouborg, 1993; Palmer, 1987; Hutchings, 1991). The evaluation of targeted species might serve as an indicator in monitoring programmes. Different populations of the targeted species can be compared on the basis of their relative densities at different phenological stages to be used as a tool in vegetation resource monitoring (Buhler and Schmed, 2001). Drastic and persistent changes in stage structure of the targeted plants could announce an imminent change and degradation in the entire plant community. The present study hypothesized that populations of targeted plants can be classified into different types that vary in the relative proportion of five life stages that can be related to harvesting, habitat loss, 
altitude and vegetation structure. Furthermore, it was expected that viable (growing or stable) population dynamics and the density of targeted plants occur more and high, respectively before collection period and in more species rich conifer vegetation of higher conservation value. Until now, it was not known whether the volume of medicinal plants currently collected for trade was tolerable or beyond the regeneration rate. In order to maintain the population size/status in the long run, there was a need to know the existing growing stock and volume of the targeted plants at the site of harvest of their habitat, distribution, availability, phenology and rate of natural regeneration.

\section{MATERIALS AND METHODS}

\section{Study site}

Malam Jabba Valley is bounded by District Shanglapar in the NorthEast, District Buner in the South-West and by main Swat River and road in the West. The area is situated between $35^{\circ}-20^{\prime}$ to $35^{\circ}-45^{\prime} \mathrm{N}$ Latitudes and $72^{\circ}-12^{\prime}$ to $73^{\circ}-32^{\prime} \mathrm{E}$ Longitudes. The altitude of the valley varies from $1200 \mathrm{~m}$ at the valley entrance to $3200 \mathrm{~m}$ at the highest peak of Shagar Sar. Population of the valley is about 40,000 people with a density of 200 persons per square kilometer $\left(/ \mathrm{Km}^{2}\right)$, with a growth rate of 3.48 (Census, 1998). The terrace is mountainous occupying the floristically rich Southern extension of Hindu Kush Raj of the Hindu Kush mountain range.

\section{Field procedure}

To assess the abundance, distribution and population of the three species in each site of the valley, transect walks were made along the important routes, throughout the targeted area covering slopes, aspects and altitudes. For every species found, the local people were asked to tell its abundance and distribution in the past. This was judged by comparing the present data with 20 years old records. In addition, personal observations were made in the field to note any pertinent events which could help gain better understanding of the presence, relative abundance based on the ecological characteristics of the species into absent, rare, very rare, occasional, frequently and dominant species. This abundance scale combines local precise knowledge of the inhabitants and personal observations made in the field to note any pertinent events giving an average percentage of abundance for a plant species. And under some circumstances, it may not be practicable to make actual counts, but plentifulness may be rapidly estimated according to the scale of abundance similar to the mentioned categories.

After a preliminary survey of the study area, 10 representative sites were selected on the basis of physiognomic contrast, altitude, habitat, species composition and stages of degradation. There were distinct south and north-east facing slopes in the Malam Jabba Hills. The general vegetation data in these two aspects was collected at five altitudinal zone viz: $1500 \mathrm{~m}$ (foot hill), 1900 to 2300 $\mathrm{m}$ (mid hills) $2700 \mathrm{~m}$, and $3200 \mathrm{~m}$ (top hill). The data of each targeted species was collected by using $10 \times 10 \mathrm{~m}$ quadrant in each site of the study. In each site $10^{2}$, each of $10 \times 10 \mathrm{~m}$ were fixed with 4 wooden pegs at 4 corners following methods of Shreshta et al. (1998) and marked for later re-identification. The quadrants were laid randomly in a nested manner. A $6 \times 6$ ha forest land in Malam site was protected for the last 3 years with the participation of the local community. The impact of protection on the regeneration and overall population size of targeted plants was recorded in $20,10 \times$
$10 \mathrm{~m}$ quadrants. There were criteria for inclusion and exclusion of individual plants occurring on the margins of the $10 \times 10 \mathrm{~m}$ quadrants.

Duplicate soil samples/site was collected from each site upto a depth of $5 \mathrm{~cm}$. Additionally, some other physical environmental parameters, such as altitude, aspect, latitude, longitude, inclination, etc. were recorded for each major plot. However, colour of the soil was noted on the spot. Life stages for each targeted plant were distinguished on the basis of field observations and the data in Ouborg (1993) and Hegland et al. (2001); these are seedling, juveniles, vegetative adults, reproductive adults and mature adults.

\section{RESULTS}

The colour of soils at different altitudes and aspects varied from grey-brownish at $1500 \mathrm{~m}$ to grey-blackish at 1900,2300 and $2700 \mathrm{~m}$ and grey at $3200 \mathrm{~m}$, in both the North-East and Southern aspects of each elevational level. Similarly, the texture of soil varied from loamy sand or sandy clay, and loamy silt to sandy clay loam. The litter contents varied from 10 to $12 \%$ on the Southern aspects and from 13 to $17 \%$ in the North Eastern aspects, which was mostly depended on the state of erosion and canopy layer. The $\mathrm{pH}$, electrical conductivity and total soluble salts did not vary much among the slopes/aspects and sites. The water holding capacity was maximum (varied from 20.45 to $33.33 \%$ ) in the North Eastern aspects with organic matter of 1.62 to 1.91 and was comparatively minimum (varied from 8.0 to $22.32 \%$ ) in the Southern aspects with organic matter of 1.3 to 1.9 (Table 1). Nitrogen contents varied from 0.2 to $0.9 \%$, with variations from $86 \mathrm{ppm}$ (1500 m Southern) to $226 \mathrm{ppm}$ (1500 m North Eastern). Similarly, phosphorus contents varied from as low as $2.1 \mathrm{ppm}$ (North East, $1900 \mathrm{~m}$ ) to $7.4 \mathrm{ppm}$ (Southern, $2700 \mathrm{~m}$ ). $\mathrm{Ca}+\mathrm{Mg}$ contents varied from 2.91 to $3.71 \%$ in the Southern aspects and from 2.41 to $3.17 \%$ in the North Eastern aspects. The water holding capacity, organic matter, $\mathrm{N}, \mathrm{P}$, and $\mathrm{K}, \mathrm{Ca}, \mathrm{Mg}$ and chloride contents exhibited significant differences in both protected and unprotected sites located at the elevation of $1900 \mathrm{~m}$ (Table 2).

\section{Abundance and distribution}

The targeted medicinal plants were found and widely distributed from lower temperate forests of lower altitude $(1500 \mathrm{~m})$ to the high altitude $(3200 \mathrm{~m})$ temperate, subalpine and alpine forests of the investigated area. However, their distribution and abundance range was influenced by altitude, aspect and slope of the area. The results (Table 3 ) showed that Persicaria amplexicaule was found in all the study sites of the investigated area except Telegram; although, frequently available in Malam, Kuh, Spinay Uba, Upper Jabba and Lower Jabba, while occasional in Kishawara. It was rarely found in Gat Sar, Shaltalu and Ilanai. The results showed that the over all population size and abundance of this 
Table 1. Texture and some physical characteristics of the soils.

\begin{tabular}{|c|c|c|c|c|c|c|c|c|c|c|c|c|}
\hline \multirow{2}{*}{ Altitude (m) } & \multicolumn{2}{|c|}{ Textural class } & \multicolumn{2}{|c|}{ Water holding capacity } & \multicolumn{2}{|c|}{$\mathrm{pH}$} & \multicolumn{2}{|c|}{$\mathrm{Ec} \times 10(\mathrm{Mmoh} / \mathrm{crm})$} & \multicolumn{2}{|c|}{ Litter (\%) } & \multicolumn{2}{|c|}{ Soil colour } \\
\hline & $\mathrm{s}$ & NE & $\mathbf{S}$ & NE & $\mathbf{S}$ & NE & $S$ & NE & $\mathbf{S}$ & NE & $S$ & NE \\
\hline 1500 & LSi & LS & 19.1 & 23.4 & 7.3 & 7.2 & 0.03 & 0.02 & 12 & 16 & G.B & G.B \\
\hline 1900 & LS & SL & 10.7 & 20.45 & 7.2 & 6.6 & 0.02 & 0.03 & 11 & 17 & $\mathrm{~Gb}$ & $\mathrm{~Gb}$ \\
\hline 2300 & SCL & LS & 13.17 & 24.54 & 7.1 & 6.8 & 0.02 & 0.01 & 10 & 14 & $\mathrm{~Gb}$ & $\mathrm{~Gb}$ \\
\hline 2700 & LSi & SL & 22.32 & 33.33 & 7.3 & 6.5 & 0.01 & 0.01 & 11 & 14 & $\mathrm{~Gb}$ & $\mathrm{G}$ \\
\hline 3200 & LSi & LS & 8.0 & 21.31 & 7.3 & 6.3 & 0.02 & 0.02 & 10 & 13 & $\mathrm{G}$ & $\mathrm{Gb}$ \\
\hline Protected site (1900) & LS & LS & 12.7 & 22.23 & 7.2 & 6.8 & 0.02 & 0.03 & 12 & 19 & $\mathrm{~Gb}$ & $\mathrm{~Gb}$ \\
\hline
\end{tabular}

Key: S, South; LS, loamy sand; NE, northeast; SL, sandy loam; G, grey; SCL, sandy clay loam; Gb, grey blackish; LSi, loamy silt ; G.B, grey brownish.

Table 2. Chemical characteristics of the soils.

\begin{tabular}{|c|c|c|c|c|c|c|c|c|c|c|c|c|c|c|c|c|c|c|}
\hline \multirow{2}{*}{$\begin{array}{l}\text { Altitude } \\
\text { (m) }\end{array}$} & \multicolumn{2}{|c|}{$\begin{array}{c}\mathrm{CaCO}_{3} \\
(\%)\end{array}$} & \multicolumn{2}{|c|}{$\begin{array}{c}\text { Organic matter } \\
\text { (\%) }\end{array}$} & \multicolumn{2}{|c|}{$\begin{array}{c}N \\
(\%)\end{array}$} & \multicolumn{2}{|c|}{$\begin{array}{c}P \\
(p p m)\end{array}$} & \multicolumn{2}{|c|}{$\begin{array}{c}\mathrm{K} \\
(\mathrm{ppm})\end{array}$} & \multicolumn{2}{|c|}{$\begin{array}{l}\text { Tss } \\
\text { (\%) }\end{array}$} & \multicolumn{2}{|c|}{$\begin{array}{c}\mathrm{HCO}_{3}{ }^{-} \\
(\%)\end{array}$} & \multicolumn{2}{|c|}{$\begin{array}{l}\mathrm{Ca}+\mathrm{Mg} \\
(\mathrm{meq} / \mathrm{L})\end{array}$} & \multicolumn{2}{|c|}{$\begin{array}{c}\mathrm{Cl} \\
(\mathrm{meq} / \mathrm{L})\end{array}$} \\
\hline & $S$ & N.E & $\mathrm{s}$ & $\mathrm{NE}$ & $\mathrm{s}$ & $\mathrm{NE}$ & $S$ & NE & $\mathrm{S}$ & NE & $\mathrm{S}$ & NE & 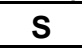 & NE & $\mathrm{s}$ & NE & $S$ & NE \\
\hline 1500 & 0.2 & 0.4 & 1.5 & 1.84 & 0.3 & 0.2 & 4.6 & 4.2 & 86 & 226 & 0.005 & 0.004 & 3.12 & 3.12 & 4.11 & 4.11 & 1.3 & 1.6 \\
\hline 1900 & 1.6 & 2.7 & 1.9 & 1.79 & 0.90 & 0.88 & 4.3 & 2.1 & 123 & 162 & 0.004 & 0.005 & 3.71 & 3.06 & 4.61 & 4.61 & 1.4 & 1.8 \\
\hline 2300 & 1.6 & 1.7 & 1.8 & 1.73 & 0.08 & 0.08 & 2.4 & 2.4 & 134 & 190 & 0.002 & 0.001 & 2.91 & 2.41 & 4.81 & 4.7 & 1.3 & 1.7 \\
\hline 2700 & 2.6 & 2.8 & 1.3 & 1.52 & 0.09 & 0.09 & 7.4 & 2.3 & 189 & 187 & 0.002 & 0.002 & 2.91 & 2.41 & 5.06 & 5.12 & 1.4 & 1.7 \\
\hline 3200 & 1.7 & 2.9 & 1.7 & 1.91 & 0.08 & 0.09 & 3.6 & 2.4 & 160 & 161 & 0.004 & 0.004 & 3.61 & 3.17 & 5.08 & 6.01 & 1.4 & 1.7 \\
\hline Protected site (1900) & 1.6 & 2.5 & 1.9 & 1.87 & 0.90 & 0.97 & 4.4 & 2.4 & 122 & 163 & 0.005 & 0.006 & 3.74 & 3.61 & 4.61 & 4.57 & 1.4 & 1.7 \\
\hline
\end{tabular}

species was slightly decreased with increasing elevation within the study area. It appeared with a high distribution frequency in Malam (65\%) and Spinay Uba (60\%), where with as $50 \%$ distribution frequency in each Kuh, Lower Jabba, and Upper Jabba. It had low distribution frequency in Gat Sar, Shaltalu and Kishawara $(30 \%$ in each site) and having $10 \%$ distribution frequency in Ilanai, while absent in Telegram. On the other hand, its distribution frequency was $95 \%$ in protected area. It was found rarely in Southern aspect and rare in the highly grazed and disturbed sites in the study area.

The results revealed that the relative abundance of Valeriana jatamansi was low in Kishawara and occasional in Spinay Uba. It was frequently available in Kuh, Malam, Lower Jabba and Upper Jabba, while in all other sites absent (Table 3 ). The overall population size and abundance of this species was increased with rising in elevation within the investigated sites in the study area. It had high distribution frequency in Upper and Lower Jabba (90\% in each site), Kuh $(70 \%)$, Malam and Spinay Uba (65\% in each site). It had
$85 \%$ distribution frequency in protected area, and was absent in Telegram, Ilanai, Shaltalu and Gat Sar, while having $15 \%$ distribution frequency in Kishawara. V. Jatamansi was found mostly growing on relatively open North East and West facing slopes and preferred moist habitat. $V$. Jatamansi was mostly associated with Geranium spp., Primula spp. and Potentilla spp. in coniferous forest. Viola serpens was distributed in all the study sites of the investigated area, although occasional in Gat Sar and frequently available in Kishawara, Spinay Uba and Upper 
Table 3. Relative abundance of targeted species in various sites of the study.

\begin{tabular}{|c|c|c|c|c|c|c|c|c|c|c|c|c|}
\hline \multirow{3}{*}{ Site } & \multicolumn{12}{|c|}{ Species } \\
\hline & \multicolumn{4}{|c|}{ P. amplexicaule } & \multicolumn{4}{|c|}{ V. jatamansi } & \multicolumn{4}{|c|}{ V. serpens } \\
\hline & $\begin{array}{l}\text { Altitude } \\
(\mathrm{m})\end{array}$ & Aspect & Slope & Abundance & $\begin{array}{l}\text { Altitude } \\
(\mathrm{m})\end{array}$ & Aspect & Slope & Abundance & $\begin{array}{l}\text { Altitude } \\
(\mathrm{m})\end{array}$ & Aspect & Slope & Abundance \\
\hline Telegram & 1200 & South & Plain & 0 & 1200 & South & Plain & 0 & 1200 & South & Plain & 1 \\
\hline Ilanai & 1300 & Southeast & Plain & 1 & 1300 & Southeast & Plain & 0 & 1300 & Southeast & Plain & 2 \\
\hline Shaltalu & 1600 & Southwest & Moderate & 2 & 1600 & Southwest & Moderate & 0 & 1600 & Southwest & Moderate & 2 \\
\hline Gat Sar & 1500 & South & Moderate & 2 & 1450 & South & Moderate & 0 & 1450 & South & Moderate & 3 \\
\hline Kishawara & 1700 & Northwest & Moderate & 3 & 1700 & Northwest & Moderate & 2 & 1700 & Northwest & Moderate & 4 \\
\hline Kuh & 2300 & North & Moderate to high & 4 & 2300 & North & Moderate to high & 4 & 2300 & North & Moderate to high & 5 \\
\hline Spinay Uba & 1800 & Northeast & Moderate to high & 4 & 1800 & Northeast & Moderate to high & 3 & 1800 & Northeast & Moderate to high & 4 \\
\hline Malam & 1900 & North & Moderate to high & 4 & 1900 & North & Moderate to high & 4 & 1900 & North & Moderate to high & 5 \\
\hline Upper Jabba & 3200 & Northwest & Moderate to high & 4 & 3200 & Northwest & Moderate to high & 4 & 3200 & Northwest & Moderate to high & 4 \\
\hline Lower Jabba & 2700 & Northeast & Moderate to high & 4 & 2700 & Northeast & Moderate to high & 4 & 2700 & Northeast & Moderate to high & 5 \\
\hline Protected area & 1900 & North & Moderate to high & 5 & 1900 & North & Moderate to high & 5 & 1900 & North & Moderate to high & 5 \\
\hline
\end{tabular}

Key: 0, Absent; 1, very rare; 2 , rare; 3 , occasional; 4, frequent; 5.

Jabba while dominant in Kuh, Malam and Lower Jabba. It was rarely found in Ilanai and Shaltalu and very rare in Telegram (Table 3 ). It was noted that the population and abundance of this species was slightly decreased with the rising in elevation within the study area. It appeared with a high distribution frequency in Malam, Spinay Uba, Kuh Lower Jabba and Upper Jabba while the species appeared with low distribution frequency in the remaining sites. $V$. serpens had $100 \%$ distribution frequency in the protected area preferring North, North East and West facing slopes. It was either occasional or rarely available in Southern or South East and West facing slopes.

\section{Population density}

The study revealed that the overall population density of targeted plant varied due to differences in sites of the investigated area as shown in Table 4. P. amplexicaule was found in very low density in Gat Sar (13), Shaltalu (21) and Ilanai (12) before collection period while available in high density in the protected site (87) and Malam (70) and closely followed by Kuh (52), Lower Jabba (48), Upper Jabba (47), Spinay Uba (44) and Kishawara (32). It is absent in Telegram. The overall population density generally showed decrease of 2 to 3 times after collection period. For instance, in Malam and Kuh, its density reduced to 31 and 17 after the collection period. A similar trend in decrease in its density was also reported in all other sites of the study area (Table 4). The density of $P$. amplexicaule was higher in the protected area in contrast to unprotected sites. Moreover, the density increased with increasing of elevation within the same locality. For instance, it was absent at $1200 \mathrm{~m}$ (Telegram) and at 1450 and $1600 \mathrm{~m}$, its density was 13 and 21 , respectively, and at 1700, 1800, 2300 and 2700 $\mathrm{m}$, it was $32,44,70$ and 52 , respectively before collection (Table 4).

V. jatamansi had low density in Kishawara (18) and Spinay Uba (25) while high density in the protected area (79), followed by Upper Jabba (71), Kuh (61), Lower Jabba (59) and Malam (54) before the collection period. It was absent in all other sites of the study area (Table 5). It was observed that its density was generally higher in the protected area in contrast to the open sites. The overall population size and abundance of this species increased with the rising of elevation. The overall density before collection was 18 at $1700 \mathrm{~m}$ (Kishawara) and 61 at $2300 \mathrm{~m}$. The density generally showed many fold decrease after collection period in each site of the study area (Table 4)

V. serpens exhibited very low density in Telegram (10), Gat Sar (14), Ilanai and Shaltalu 
Table 4. Density, frequency and herbage cover of targeted plants before and after collection period at various locations of the study.

\begin{tabular}{|c|c|c|c|c|c|c|c|c|c|c|c|c|c|c|c|c|c|c|c|c|c|c|c|c|}
\hline \multirow{4}{*}{$\begin{array}{l}\text { Site /Altitude } \\
\quad(\mathrm{m})\end{array}$} & \multicolumn{24}{|c|}{ Species } \\
\hline & \multicolumn{8}{|c|}{ P. amplexicaule } & \multicolumn{8}{|c|}{ V. jatamansi } & \multicolumn{8}{|c|}{ V. serpens } \\
\hline & \multicolumn{4}{|c|}{$\begin{array}{c}\text { Before collection } \\
\text { April, } 2002 \text { - May, } 2004\end{array}$} & \multicolumn{4}{|c|}{$\begin{array}{c}\text { After collection } \\
\text { August, } 2002 \text { - September, } \\
2004\end{array}$} & \multicolumn{4}{|c|}{$\begin{array}{c}\text { Before collection } \\
\text { April, } 2002 \text { - May, } 2004 \\
\end{array}$} & \multicolumn{4}{|c|}{$\begin{array}{c}\text { After collection } \\
\text { August, } 2002 \text { - September, } \\
2004\end{array}$} & \multicolumn{4}{|c|}{$\begin{array}{c}\text { Before collection } \\
\text { April, } 2002 \text { - May, } 2004\end{array}$} & \multicolumn{4}{|c|}{$\begin{array}{c}\text { After collection } \\
\text { August, } 2002-\text { September, } \\
2004 \\
\end{array}$} \\
\hline & D & $\mathbf{F}$ & H.C & L.S & D & $\mathbf{F}$ & H.C & L.S & D & $\mathbf{F}$ & H.C & L.S & D & $\mathrm{F}$ & H.C & L.S & D & $\mathbf{F}$ & H.C & L.S & D & $\mathbf{F}$ & H.C & L.S \\
\hline Talegram / 1200 & 0.0 & 0.0 & 0.0 & 0.0 & 0.0 & 0.0 & 0.0 & 0.0 & 0.0 & 0.0 & 0.0 & 0.0 & 0.0 & 0.0 & 0.0 & 0.0 & 10 & 10 & 11 & Rep & 4 & 8 & 7 & $\mathrm{Ma}$ \\
\hline Ilanai / 1300 & 12 & 10 & 5 & Ju & 7 & 90 & 2 & $\mathrm{Ma}$ & 0.0 & 0.0 & 0.0 & 0.0 & 0.0 & 0.0 & 0.0 & 0.0 & 17 & 20 & 10 & Rep & 6 & 15 & 4 & $\mathrm{Ma}$ \\
\hline Gat Sar / 1500 & 13 & 30 & 7 & $\mathrm{Ju}$ & 9 & 20 & 3 & $\mathrm{Ma}$ & 0.0 & 0.0 & 0.0 & 0.0 & 0.0 & 0.0 & 0.0 & 0.0 & 14 & 30 & 10 & Rep & 5 & 15 & 5 & $\mathrm{Ma}$ \\
\hline Shaltalu / 1600 & 21 & 30 & 9 & Veg & 7 & 20 & 4 & $\mathrm{Ma}$ & 0.0 & 0.0 & 0.0 & 0.0 & 0.0 & 0.0 & 0.0 & 0.0 & 17 & 30 & 11 & Rep & 6 & 10 & 6 & $\mathrm{Ma}$ \\
\hline Kishawara / 1700 & 32 & 30 & 12 & Veg & 12 & 15 & 5 & $\mathrm{Ma}$ & 18 & 15 & 10 & Veg & 6 & 5 & 5 & $\mathrm{Ma}$ & 19 & 45 & 15 & Rep & 8 & 20 & 6 & $\mathrm{Ma}$ \\
\hline Spinay Uba / 1800 & 44 & 60 & 19 & Ju & 19 & 35 & 7 & Rep & 25 & 65 & 15 & Veg & 14 & 30 & 6 & $\mathrm{Ma}$ & 47 & 60 & 20 & Rep & 19 & 25 & 8 & $\mathrm{Ma}$ \\
\hline Malam / 1900 & 70 & 65 & 32 & Veg & 31 & 25 & 13 & $\mathrm{Ma}$ & 54 & 65 & 20 & Veg & 17 & 20 & 9 & $\mathrm{Ma}$ & 71 & 80 & 31 & Rep & 24 & 35 & 11 & $\mathrm{Ma}$ \\
\hline Kuh / 2300 & 52 & 50 & 40 & Veg & 17 & 20 & 15 & $\mathrm{Ma}$ & 61 & 70 & 20 & Veg & 23 & 35 & 8 & $\mathrm{Ma}$ & 19 & 60 & 29 & Rep & 27 & 25 & 10 & $\mathrm{Ma}$ \\
\hline Lower Jabba / 2700 & 48 & 50 & 40 & Veg & 13 & 20 & 19 & $\mathrm{Ma}$ & 59 & 90 & 22 & Veg & 21 & 40 & 11 & $\mathrm{Ma}$ & 80 & 95 & 35 & Rep & 36 & 30 & 10 & $\mathrm{Ma}$ \\
\hline Upper Jabba / 3200 & 47 & 50 & 27 & $\mathrm{Ju}$ & 12 & 25 & 16 & $\mathrm{Ma}$ & 71 & 90 & 35 & Veg & 27 & 50 & 13 & $\mathrm{Ma}$ & 42 & 45 & 30 & Rep & 19 & 30 & 10 & $\mathrm{Ma}$ \\
\hline Protected area / 1900 & 87 & 95 & 55 & veg & 95 & 100 & 60 & $\mathrm{Ma}$ & 79 & 85 & 40 & Veg & 88 & 90 & 60 & $\mathrm{Ma}$ & 91 & 100 & 45 & $\operatorname{Rep}$ & 99 & 90 & 52 & $\mathrm{Ma}$ \\
\hline
\end{tabular}

Key: D, Density; F, frequency; H.C, herbage cover; L.S, life stage; Veg, vegetative adult; Rep, reproductive adult; Ma, mature; Ju, juvenile.

Table 5. Average biomass production of targeted plants in various sites of Malam Jabba, Swat, Pakistan from 2002 to 2004.

\begin{tabular}{|c|c|c|c|c|c|c|}
\hline \multirow{3}{*}{ Site } & \multicolumn{6}{|c|}{ Species } \\
\hline & \multicolumn{2}{|c|}{ P. amplexicaule } & \multicolumn{2}{|c|}{ V. jatamansi } & \multicolumn{2}{|c|}{ V. serpens } \\
\hline & $\begin{array}{l}\text { Average fresh biomass } \\
\left(\mathrm{g} / 2 \times 2 \mathrm{~m}^{2}\right)\end{array}$ & $\begin{array}{l}\text { Average dry biomass } \\
\left(\mathrm{g} / 2 \times 2 \mathrm{~m}^{2}\right)\end{array}$ & $\begin{array}{l}\text { Average fresh biomass } \\
\left(\mathrm{g} / 2 \times 2 \mathrm{~m}^{2}\right)\end{array}$ & $\begin{array}{l}\text { Average dry biomass } \\
\left(\mathrm{g} / 2 \times 2 \mathrm{~m}^{2}\right)\end{array}$ & $\begin{array}{l}\text { Average fresh biomass } \\
\left(\mathrm{g} / 2 \times 2 \mathrm{~m}^{2}\right)\end{array}$ & $\begin{array}{l}\text { Average dry biomass } \\
\left(\mathrm{g} / 2 \times 2 \mathrm{~m}^{2}\right)\end{array}$ \\
\hline Telegram & --- & --- & --- & -- & 90.61 & 33.45 \\
\hline Ilanai & 114.67 & 60.62 & --- & --- & 70.89 & 23.42 \\
\hline Gat Sar & 189.23 & 73.78 & --- & --- & 80.63 & 29.63 \\
\hline Shaltalu & 137.56 & 84.92 & --- & --- & 120.32 & 37.46 \\
\hline Kishawara & 203.45 & 93.67 & 137.31 & 87.42 & 289.56 & 97.78 \\
\hline Spinay Uba & 642.5 & 347.67 & 389.62 & 114.78 & 169.45 & 109.61 \\
\hline Malam & 700.83 & 359.61 & 471.66 & 181.54 & 392.51 & 117.72 \\
\hline Kuh & 989.78 & 411.34 & 659.52 & 283.36 & 263.69 & 121.47 \\
\hline Lower Jabba & 1000.93 & 371.32 & 989.67 & 342.23 & 442.67 & 193.93 \\
\hline Upper Jabba & 989.67 & 44.45 & 1472.63 & 479.17 & 189.72 & 99.32 \\
\hline Total & 4968.62 & 2214.38 & 4120.41 & 1058.5 & 2110.05 & 876.67 \\
\hline Protected area & 1314.67 & 414.32 & 789.89 & 387.42 & 772.67 & 387.87 \\
\hline
\end{tabular}


(17 each) and Kishawara (19) while high density in protected area (91) and Lower Jabba (80). It was closely followed by Kuh (79), Malam (71), Spina Uba (47) and Upper Jabba (42). The results showed that the density of $V$. serpens was high in the protected area as compared to open habitat (Table 4). Moreover, it had lowest density at lower altitude which increased with the increasing of elevation especially upto $2700 \mathrm{~m}$ but gradually decreased with further rising of elevation. For instance, the density was 10,71, 79 and 80 at 1200, 1800, 2300 and $2700 \mathrm{~m}$, respectively, while at $3200 \mathrm{~m}$, the density was 42 before collection period (Table 5).

\section{Herbage cover}

A high herbage cover was recorded for $P$. amplexicaule in Kuh and Lower Jabba (40\% each), followed by Malam (32\%) and Upper Jabba (27\%), Spinay Uba (19\%), Kishawara (12\%) and lowest in Ilanai $(5 \%)$, Gat Sar $(7 \%)$ and Shaltalu $(9 \%)$ before the collection period. This species was absent in Telegram, while its herbage cover was highest in the protected area (55\%) as compared to unprotected sites (Table 4).

$V$. jatamansi had minimum herbage cover in Kishawara $(10 \%)$ and Spinay Uba (15\%) while maximum herbage cover in protected area (40\%). It was closely followed by Upper Jabba (35\%), Lower Jabba (22\%), Kuh and Malam ( $20 \%$ each) before collection period. It was absent in all other sites of the study area (Table 4).

The results (Table 5) showed that the herbage cover of $V$. serpens was more in the protected site $(45 \%)$ in contrast to unprotected area; while in Lower Jabba, its herbage cover was 35\% followed by Malam (31\%), Upper Jabba (30\%) and Kuh (29\%) before the collection period. It produced minimum herbage cover in the remaining sites of the study area and varied from 10 to $20 \%$ before the collection period. The study revealed that in open habitat, the herbage cover of each targeted plants was generally decreased 2 to 3 times after the collection period, while in the protected area it slightly increased after collection period (Table 4). It was noted that the cover of targeted species was generally increased with the increase of altitude within the study area (Table 4).

\section{Biomass production}

The present study evaluated the total biomass in terms of dry and fresh weight per $2 \times 2 \mathrm{~m}$ area of $P$. amplexicaule that varied considerably in the 11 different sites of the study area (Table 5). A perusal of the data showed that the total underground biomass (dry weight) of $P$. amplexicaule was highest in protected sites (414.32 g), followed by Kuh and Upper Jabba (each had $411.34 \mathrm{~g}$ ), Lower Jabba (371.32g), Malam (359.61g) and Spinay Uba (347.67 g); these are the higher altitude sites varying from 1800 to 3200 m, while in Kishawara, Shaltalu, Gat
Sar and Ilanai are 93.67, 84.92, 73.78 and $60.62 \mathrm{~g}$ per 2 $\times 2 \mathrm{~m}$ area, respectively (Table 5 ).

It was observed that $V$. jatamansi produced maximum biomass of $479.17 \mathrm{~g} / 2 \times 2 \mathrm{~m}$ area in Upper Jabba. It was closely followed by protected site $(387.42 \mathrm{~g} / 2 \times 2 \mathrm{~m})$ and Lower Jabba $(342.23 \mathrm{~g} / 2 \times 2 \mathrm{~m})$. $V$. jatamansi had the minimum $283.36 \mathrm{~g} / 2 \times 2 \mathrm{~m}, 181.54 \mathrm{~g} / 2 \times 2 \mathrm{~m}$ and 114.78 $\mathrm{g} / 2 \times 2 \mathrm{~m}$ biomass in Kuh, Malam and Spinay Uba, respectively, while least in Kishawara $(87.42 \mathrm{~g} / 2 \times 2 \mathrm{~m})$ (Table 5).

The maximum above ground biomass of $V$. serpens was $388.87 \mathrm{~g} / 2 \times 2 \mathrm{~m}$ in protected site, followed by Lower Jabba $(193.93 \mathrm{~g} / 2 \times 2 \mathrm{~m})$, Kuh $(121.47 \mathrm{~g} / 2 \times 2 \mathrm{~m})$ and Malam $(117.72 \mathrm{~g} / 2 \times 2 \mathrm{~m})$, while $109.61 \mathrm{~g} / 2 \times 2 \mathrm{~m}, 99.32$ $\mathrm{g} / 2 \times 2 \mathrm{~m}$, and $97.78 \mathrm{~g} / 2 \times 2 \mathrm{~m}$ in Spinay Uba, Upper Jabba and Kishawara, respectively. The least value was $23.42 \mathrm{~g} / 2 \times 2 \mathrm{~m}, 29.63 \mathrm{~g} / 2 \times 2 \mathrm{~m}, 33.45 \mathrm{~g} / 2 \times 2 \mathrm{~m}$ and $37.46 \mathrm{~g} / 2 \times 2 \mathrm{~m}$ in Ilanai, Gat Sar, Telegram and Shaltalu, respectively (Table 5 ).

The present study revealed that the total underground biomass productivity of $P$. amplexicaule and $V$. jatamansi was $2628.7 \mathrm{~g} / 2 \times 2 \mathrm{~m}$ and $1445.92 \mathrm{~g} / 2 \times 2 \mathrm{~m}$ (dry weight), respectively while above ground biomass of $V$. serpens was $1264.54 \mathrm{~g} / 2 \times 2 \mathrm{~m}$ in all the investigated sites of Malam Jabba (Table 5). The study generally observed that the total biomass in terms of dry weight of each targeted plant was higher at high altitude and most particular in protected sites. It might be due to the presence of more wetter and gentle, slope North, North East and West facing slopes with high organic matter contents in the soil. The other sites like Telegram, Ilanai, Shaltalu and Gat Sar were comparatively dry and open due to over grazing and deforestation and had South, South East and West facing slopes with lesser organic content in the soil. Moreover, these sites were comparatively more accessible for human interference than the other study sites.

\section{Population dynamics}

The targeted plants are rhizomatous species and spread by the natural multiplication of vegetative offshoots (rhizomes) and seeds. Analysis of the population structure (different life stages) of targeted plants species showed that only few individuals of targeted species reached to maturity throughout the investigated area. The results revealed (Table 5 ) that the density of mature plants reduced 3 to 4 folds (after collection) than the overall density before collection. But only few plants of the targeted species set their fruits and seeds which were inappropriate for the establishment of their population within the existing vegetational community.

The density of mature plants of all targeted plants was comparatively higher at 1800, 1900, 2300, 2700 and $3200 \mathrm{~m}$ elevations. For instance, the density of mature plants of $V$. jatamansi was 8 at $1800 \mathrm{~m}$ followed by 13 at 
$2300 \mathrm{~m}, 18$ at $2700 \mathrm{~m}$ and 20 at $3200 \mathrm{~m}$, and the density of mature plants of $V$. serpens was 12,16 and 18 at 1800,2300 , and $2700 \mathrm{~m}$ altitude, respectively; while the density of mature individuals of $P$. amplexicaule was 15 at $1800 \mathrm{~m}$ followed by 7,9 and 10 at 1800,2300 and $2700 \mathrm{~m}$ elevation, respectively (Table 5). The results also indicated (Table 5) that a significant difference also existed in the density of different life stages of targeted plants before and after collection and population density decreased 3 to 5 times after harvesting. Density of mature individuals was lower at lower altitude (ranges from 1200 to $1700 \mathrm{~m}$ ) and the density of mature individual of each plant was 2 to 3 times lower than the site located at high altitude (Table 5). The study also revealed that the density of mature plants of each targeted species was 3 to 4 times higher in protected site as compared to all other open habitats (Table 5).

\section{DISCUSSION}

The soil of the investigated area was generally low in nutrients. This could be due to erosion which has removed the top fertile layer and organic matter which is raw material for nutrient release. Other workers also reported low nutrient status of the soil due to deforestation and erosion from various parts of Swat and our findings of study is consistent with them (Vladychensky,1992). At certain places, the water holding capacity was relatively high, probably due to high organic matter contents.

The targeted species namely, $P$. amplexicaule, $V$. jatamansi and $V$. serpens are found in almost all habitats throughout the study area that is, from temperate forests to sub-alpine and alpine pastures and meadows. However, the distribution is influenced by altitude, aspect and inclination of the slope. These findings are in agreement with other studies showing that the population of Valeriana spp., V. serpens, Dioscorea deltoidea and Persicaria spp. are higher in the sub-alpine and alpine pastures (Shrestha et al., 1998). While the pattern of distribution and availability of targeted plants were found to be quite variable according to differences in harvesting intensity, grazing and habitat loss. These factors have adversely affected the natural regeneration and seriously reduced the availability of targeted plants in particular sites of the study area. Secondly, the number of endangered species is increasing every day due to environmental degradation, and indiscriminate collection. The findings of Sher et al. (2012) also supported our results as they observed that topographic, edaphic and biotic factors determine the shape, distribution and availability of vegetation structure. The present study found that the targeted plants mostly grow and occur on relatively open north east facing slopes, and prefer moist habitat. $P$. amplexicaule, $V$. jatamansi and $V$. serpens were found mostly associated with each other under the coniferous shade. These were found very rarely in highly grazed and disturbed sites near the villages. The present study also found that the existence and distribution of targeted plants themselves are the result of interactions of physical and biotic factors within different habitats. This may give valuable indications to the characteristics of the habitats for other associated important species. The findings of Sikarwar (1996) support our results as he also noted that plant community association and structure support each other population. The population status of targeted species at lower altitude was highly threatened due to intensive agriculture and expansion of settlements coupled with over harvesting and over grazing. It was generally observed that $P$. amplexicaule and $V$. serpens are palatable but non-preferred species for cattle, goats and sheep and also for wild animals, while $V$. jatamansi is either non-palatable or a non-preferred species for all kinds of animals including domestic and wild. However, over grazing and trampling damages the plants, young seedlings and influences their habitat and species composition.

\section{Population density}

The overall population density and coverage varied considerably in different sites of the investigated area. The overall population density and coverage of targeted species generally showed 40 to $50 \%$ decrease after collection. We observed that the low population density (and coverage of targeted plants) after collection period throughout the sampling sites was due to some biotic disturbances. Three major disturbance factors have been identified viz: 1) overharvesting, 2) overgrazing and 3) habitat loss (in form of deforestation and encroachment for cultivation). Sign of habitat loss was mostly observed at lower altitude. The sign of overharvesting and overgrazing was observed throughout the investigated area. Sher et al. (2011) also revealed that the targeted plants are traded in large amounts which are indicative of their overharvesting. Our findings are in line with those of Belal and Springuel (1996). They reported that forest degradation by deforestation and overgrazing has seriously reduced the population size and density of nontimber forest products in Dolpa forest of Nepal. These three disturbances have induced severe effect on the overall population size and density of our targeted plants. The present study found that these disturbances have caused many folds decrease in the population size and density of targeted plants in the investigated area. The results of the present investigation were very promising in protected site (Malam- $1900 \mathrm{~m}$ ) of the study area. The population density and coverage of targeted plants were increasing in protected areas. The results also revealed that the studied parameters of targeted plants were about $40 \%$ high in protected site (Malam-1900 m) over all other open sites. Similar results were also reported by Khan 
(1994) who reported that protection might help in the revival of original vegetation and recovery of natural habitats where degradation result due to heavy biotic interference. The results of the present study revealed that in unprotected sites of the study area, targeted plants were declining very rapidly. As a result, these species occur rare in some of the sites of the present study area. It might be due to over extraction, grazing, and deforestation. These species have been extracted so heavily in the past that they are found now sparsely in some of the localities. Similar results were also reported by Shaw and Shinwari (1996) who stated that Potentilla species are threatened and becoming extinct by over use and habitat destruction in Pakistan. The study revealed that the overall population size of targeted plants was mainly governed by altitude and aspect, and showed an increase of 3 to 5 times with rise in altitude. Furthermore, it was also observed that parameters determined for each targeted plants appeared with promising results in the North, Northeast and West facing aspects in contrast to South, Southeast and West facing aspects. The study generally observed that key stone/umbrella species of targeted plants were mostly present on Northeast and West facing slopes in the study area. Therefore, targeted plants have significant population size and density in the North, Northeast and West facing slopes. This agrees with the finding of Tuxil and Nabhan (1998) who reported that key stone species and other association of plants of the same habitat are needed for ecological communities, which provide favourable micro-habitats such as shady cover from intense sun and buffering from cold winter night air. Sher et al. (2011) also reported that north facing slope were relatively cooler than south facing slopes. The south facing slopes were relatively unfavourable in comparison to the north facing slopes and therefore, the production of targeted plants declined on these slopes.

Biomass is a manifestation of net production. All the plants do not have the same metabolic rate; hence, their production performance within the community differs. The differences are also determined by the age of the plants, leaf area and seasonal changes which affect the physiological process of each species (Sher et al., 2012). Biomass varies considerably over the landscape due to climatic, edaphic and topographic differences as well as history of biotic disturbances (Buhler and Schmed, 2001; Sher et al., 2011). Biomass production rate is an indicator to the performance of a species within a community. Species with higher biomass and higher production rates are dominant in plant communities and they also influence the appearance or physiognomy of the vegetation (Sher et al., 2012). The biomass is not uniformly distributed throughout the plant body. Much of the matter is stored in storage organs of the plants like rhizomes, stems, tubers etc. During the present investi-gation, almost all useful rhizomes of targeted plants were gathered from a unit area $(2 \times 2 \mathrm{~m})$ and their weight was taken before and after drying at $80^{\circ} \mathrm{C}$ (oven) up to a constant weight.

The targeted plants are rhizomatous species and spread by the natural multiplication of vegetative offshoots (rhizomes) and seeds.

The analysis of the population structure (different life stages) of targeted plants showed that only few individuals reached to maturity within the investigated area. The results revealed that the density of mature plants reduced 2 to 3 times (after collection) in comparison to the overall density before collection. Only few plants set fruits and seeds which may not be enough for the future existence of their population within the existing plant community.

The density of mature plants of all targeted plants was comparatively high at higher elevation in contrast to lower elevation. Similarly, a significant difference also exists in the densities of different life stages of targeted plants before and after collection period. At all stages, the density decreases 2 to 3 -fold after the harvesting period.

\section{ACKNOWLEDGEMENT}

The Researches Centre at the faculty of arts at the University of King Saud has financed this research, we are thankful for their support.

\section{REFERENCES}

Belal AE, Springuel I (1996). Economic value of plant diversity in arid environments. Nat. Resour. 32(1):33-38.

Buhler KC, Schmed B. (2001) The influence of management regime and altitude on the population structure of Succisa pratensis implication for vegetation monitoring. J. Appl. Ecol. 48:689-698.

Census Report of District Swat (1998). Population census organization, Statistical Division Govt. Pak, Islamabad, pp. 10-89.

Hegland SJ, Merijn VL, Gerard BO (2001). Population structure of Salvia pratensis in relation to vegetation and management of Dutch dry flood plain grasslands. J. appl. Ecol. 38(6):1277-1289.

Hutchings MJ (1991) Monitoring plant population; Census as an aid to conservation. Monitoring for conservation and ecology (ed. Goldsmith FB), Champan and Hall London, UK, pp. 61-76.

Khan AU (1994). Appraisal of Ethnoecological incentives to promote conservation of Salvadora oleoides Dine the cse for creating a resource area. Biol. Conserv. 75(2):187-190.

Ouborg NJ (1993). On the relative contribution of genetic erosion to the chance of population extinction. Ph.D thesis. University of Utrecht, Utrecht, the Netherlands, pp. 111-113.

Palmer ME (1987). A critical look at rare plant monitoring in the United States. Biol. Conserv. 39:113-127.

Rabotnow TA (1985). Dynamics of plant coonotic populations. Handbook of vegetation science. The population structure of vegetation (ed. White J), Junk Publishers, Dordrecht, The Netherlands, 3:121-143.

Shaw MS, Shinwari ZK (1996) Traditional uses of Potentilla species in Pakistan. Proceeding of First Training workshop on Applied Ethnobotany, NARC, Islamabad, pp. 158-164.

Sher H, Ali A (2012). Overview on the ecological and geographical appraisal of important medicinal and aromatic plants: An endangered component in the flora of Saudi Arabia. Sci. Res. Essays 7(16):1639 1646.

Sher H, Mohammad A, Abdur RK, Amjad S (2011). Assessment of local management practices on the population ecology of some medicinal plants in the coniferous forest of northern parts of Pakistan. 
Saudi J. Biol. Sci. 18:141-149.

Sher H, Khalid AM, Mashhor M (2012). Study on the ethnopharmaceutical values and traditional uses of Capparis spinosa L. Afr. J. Pharm. Pharmacol. 6(16):1255-1259.

Shrestha KK, Ghimire SK, Gurung TN, Lama YC (1998). Conservation of plant resources, Community Development and training in applied ethnobotany in Nepal. Final Report Prepared by WWF-Nepa Programme and people and plants initiative.
Tuxill J, Nabhan GP (1998). Plants and protected areas: a guide to insitu management. People and plants conservation manual. Stanley Thornes (Publishers) Ltd, UK. pp. 14-34.

Vladychensky AS (1992). Study on soil cover differentiation in the alpine belt of West Caneasus Moscow. Univ. Soil. Sci. Bull. 47(4):38-45. 